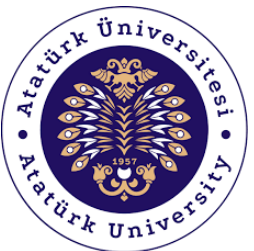

Atıf/Citiation
Doğu Coğrafya Dergisi

Aralık-2020, Y11: 25, Say1: 44, Sayfa: 1-12

Eastern Geographical Rewiew

December-2020 Volume: 25, Numbers: 44, Page: 1-12

DOİ: https://doi.org/ 10.17295/ataunidcd.795280

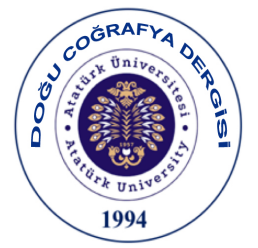

Özpay, A, G., Akpınar, E.,(2020), Kültürel mirasa bir örnek: Sivas cer atölyesi. Doğu Coğrafya Dergisi 25(44), 1-12

\title{
KÜLTÜREL MİRASA BİR ÖRNEK: SIVAS CER ATÖLYESİ
}

An Example to Cultural Heritage: Sivas Traction Factory

\author{
Prof.Dr. Gülpınar AKBULUT ÖZPAY ${ }^{1}$ \\ Prof.Dr. Erdal AKPINAR ${ }^{2}$
}

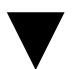

$\ddot{\boldsymbol{O}} \boldsymbol{z}$

Bu çalışmanın konusu, Türkiye’nin önemli kültürel miras varlıklarından biri olan Sivas Cer Atölyesi'dir. Tespitlerimize göre, 22 Ekim 1939 tarihinde Sivas'da kurulan atölye; tarihi ve mimarisi yanında, geçmişte Sivas'ın ve Türkiye'nin ekonomisine yapmış olduğu katklyla da kültürel miras olarak nitelendirilmeyi hak etmektedir. Bu araştırmada, 80 yıllık bir geçmişi olan Sivas Cer Atölyesi tarihi kayıtlardan, tarafimızdan yapılan saha gözlemlerinden ve görüşmelerden elde edilen verilerle analiz edilmiş ve yorumlanmıştır. Çalışmada atölyenin tarihi gelişimi ayrıntılı bir şekilde ele alınmış; kuruluş yeri, mimarisi ve müzesi bir bütün olarak değerlendirilmiştir. Bu çalışmayla, Cumhuriyetin ilk modern sanayi kuruluşlarından olan ve şehrin toplumsal belleğinde önemli bir yer tutan Sivas Cer Atölyesi'nin tanitılması ve kültürel miras kimliğiyle gelecek kuşaklara aktarılması hedeflenmektedir.

Anahtar Kelimeler: Sivas, Kültürel Miras, Cer Atölyesi, Lokomotif.

\section{Abstract}

Subject of this study is Sivas traction factory which is one of most important cultural heritage properties of Turkey. According to our determination, the factory that is established in Sivas on 22nd october 1939 deserves to be qualified as the "cultural heritage properties of Turkey" because of its history and architecture and besides its contribution to Turkey and Sivas' economy in the past. In this study Sivas traction factory with its 80 years of history is analysed and interpreted with its historical records, field observations which is made by us and interviews. In the study historical development of the workshop is contextualized and deal with its site of establishment, architecture and museum entirely. Introduction of Sivas traction factory, which is one of the first modern industrial enterprise of our republic and has an important place in social memory, and handing down the next generations with its cultural heritage identity is aimed.

Keywords: Sivas, Cultural Heritage, Traction Factory, Locomotive.

\footnotetext{
${ }^{1}$ Sivas Cumhuriyet Üniversitesi Eğitim Fakültesi Türkçe ve Sosyal Bilimler Eğitimi Bölümü gakbulut58@gmail.com, ORCID ID: 0000-0002-5943-7747

${ }^{2}$ Erzincan Binali Yıldırım Üniversitesi Fen Edebiyat Fakültesi Coğrafya Bölümü eakpinar@erzincan.edu.tr, ORCID ID:00000002-5281-9785.
} 


\section{Giriş}

Yaşadığımız çağda her ülke, sahip olduğu doğal ve kültürel varlıkları korumak ve uluslararası alanda tanıtabilmek için çaba göstermektedir (Akpınar, 2007: 82). Kuşkusuz ekonomik bakımdan büyük masraflar gerektiren bu çabanın bazı önemli nedenleri vardır. Bunların başında mevcut değerleri gelecek nesillere aktarabilme, medeniyetler arası mücadelede üstünlük kurma ve ülkeler arasında itibarlı bir konuma sahip olma arzusu gelir (Özgüç, 1998: 160-163). Çok daha önemlisi ise, hızla gelişmekte olan küresel turizm pastasından pay alma isteğidir. Nitekim 'miras turizmi' olarak da adlandırılan bu sektör, dünya genelinde giderek önem kazanmaktadır (Shaffer \& Inglis, 2000: 73).

Kültürel miras; "geçmişten miras alınan ve değişik gerekçelerle geleceğe miras bırakılmak istenilen, fiziksel olarak varlığı olan ve insanlar tarafindan yapılmış her türlü eserler ile bir topluma ait değerler bütünü" olarak tanımlamıştır (Can, 2009: 3). Bu tanımın içeriği zamanla zenginleşmiş; mimari yapı, tarihi bina veya anıt gibi maddi öğeleri; örf, adet, gelenek, şölen ve yaşam tarzı gibi maddi olmayan öğelerin tümünü içine alan kültürel çevre olarak kabul edilmiştir (Yılmaz, 2005: 6). Günümüzde kültürel miras somut kültürel miras ve somut olmayan kültürel miras olarak ikiye kategoride ele alınmaktadır. Somut kültürel miras; "binaları, tarihi yerleri, anıtları ve insan eliyle yapılmış herşeyi kapsar. Gelecek nesiller için korunması, saklanması önemli görülen eserlerdir." (Can, 2009:3). 16 Kasım 1972 tarihinde Birleşmiş Milletler Eğitim, Bilim ve Kültür Örgütü (UNESCO) tarafından kabul edilen Dünya Doğal ve Kültürel Mirası Koruma Sözleşmesi (Convention Concerning the Protection of the World Cultural and Natural Heritage) olarak kayda geçen 38 maddeden oluşan sözleşmenin 1. maddesinde, kültürel miras kavramı; "tarih, sanat veya bilim açısından evrensel değere sahip mimarî yapı, heykel, resim, sit alanı, arkeolojik yapıt, kitâbe, mağara, ayrı veya birleşik yapı topluluğu ile tarihsel, estetik, etnolojik veya antropolojik bakımdan evrensel niteliği olan insan veya insan-doğa bileşimi eserler" olarak tanımlanmıştır (Girişken, 2010:5). Ancak bu süreçte toplumsal belleğin korunmasında etkin rol oynayan somut olmayan kültürel ögeler göz ardı edilmiştir. Somut olmayan kültürel miras; "gelenek, dil, inanışlar, folklorik unsurlar, tekerlemeler, hikâyeler ve şiirler gibi elle tutulamayan, gözle görülmeyen ancak toplumu var eden değerlerdir" (Can, 2009: 1).

Toplumlar yaşadıkları coğrafî mekân üzerinde gelişen ve değişen olaylardan edindikleri tecrübe ve deneyimlerini, somut ve somut olmayan kültür değerlerini gelecek kuşaklara aktarırlar. Esasen bu değerler toplumsal belleğin ve yaşam tarzının temsilcisi olan kültürü tarif eder. Bir toplumun kültürünü temsil eden değerlerin sürdürülebilirliği, kültürel mirasın korunması ile mümkündür. Kültürel mirasın korunmasına yönelik adımlar II. Dünya Savaşıı'ndan sonra atılmış, 14 Mayıs 1954 tarihinde UNESCO tarafindan Silahlı Çatışma Durumunda Kültürel Mirasın Korunması Sözleşmesi ve Protokolü imzalanmıştır (Oğuz, 2013: 6).

“Özellikle 1972 tarihli Kültürel ve Doğal Mirasın Korunması Sözleşmesi’nde tanımı yapılan kültürel mirasın tamamen somut oluşu, 2003 tarihli Somut Olmayan Kültürel Mirasın Korunması Sözleşmesi'nin hazırlanma gerekçesinin ve adının belirlenmesinde etkili olmuştur. 1972 Sözleşmesi'nin kabulünden sonraki dönemde UNESCO belgelerinde sırayla folklor, popüler ve geleneksel kültür, maddi olmayan miras, sözlü ve somut olmayan kültürel miras gibi terimler kullanılmıştır. 1973 Tarihli Bolivya Bildirgesi'nde folklor, UNESCO içinde 1982 yılında kurulan bölüme maddi olmayan kültür, 1989 Tavsiye Kararı'nda popüler ve geleneksel kültür,1997/98 Başyapıtlar İlan Programı'nda sözlü ve somut olmayan kültürel miras terimleri tercih edilmiştir. Ancak, UNESCO içinde Sözleşme metninin hazırlık döneminde 2002-2003 yıllarında yapılan hükümetler arası uzmanlar toplantılarında korunması istenen alanı kapsayacak en uygun terimin 'somut olmayan kültürel miras' olduğu sonucuna varılmış ve sözleşme metninde hem folklor, antropoloji ve etnoloji adlarına, hem de UNESCO belgelerinde daha önce kullanılan diğer terimlere yer verilmemiştir" (Oğuz, 2013: 5).

Somut ve somut olmayan kültürel mirasın korunmasına yönelik bütünsel bir yaklaşım önemli ve gereklidir (Metin Basat, 2013: 63). Bu çalışmada Cumhuriyetin ilk yıllarında kurulan ve Türkiye'nin önemli sanayi kuruluşlarından biri olan Sivas Cer Atölyesi'nin kültürel miras özelliği ele alınmıştır. Konu atölyenin tarihi, somut ve somut olmayan kültürel miras başlıkları altında incelenmiştir.

\section{Yöntem}

Çalışmada tarama yöntemi kullanılmış olup, bu kapsamda öncelikle literatür taraması yapılmıştır. Saha çalışması çerçevesinde atölye gezilmiş ve fotoğraflanmış, çalışanlar ile mülakatlar yapılmıştır. Ele edilen veriler ve belgeler üzerinden Sivas Cer Atölyesi'nin kültürel miras öğeleri analiz edilmiş ve yorumlanmıştır. 


\section{Sivas Cer Atölyesi (TÜDEMSAŞ)}

\subsection{Atölyenin Kuruluş ve Gelişimi}

Cumhuriyetin temellerinin atıldığı Sivas şehrinde Ulu Önder Mustafa Kemal Atatürk, ülkenin o dönem en önemli sanayi kuruluşlarından biri olan lokomotif ve vagon üretim atölyesinin kurulması talimatını vermiştir. Talimat doğrultusunda 20 Temmuz 1936 tarihinde atölyenin temeli atılmışıı (Yıldırım, 1993: 248; Mahiroğulları, 2009: 178). Atölyenin kuruluş yeri Sivas kalesinin güneyinde Ermeni mezarlı̆̆ından başlayıp, Kızılırmak nehrine kadar geniş bir alan kaplayan Paşa Çayırı mevkii olarak belirlenmiştir. Bu çerçevede Kaleardı mahallesi güney kesimleri ve Kayserikapı Mezarlığı ile Ece Mahallesindeki Kestekli Mezarlığı arasında kalan arazi atelyenin inşaası için kamulaştırılmıştır (Üredi, 2006: 252). Yer tespiti yapılan arazinin taban suyu seviyesinin yüksek oluşu nedeniyle inşaatın zeminini sağlamlaştırmak için yüzlerce beton kazık çakılmıştır. İnşaat malzemesi yakın çevreden ve yeni kurulan tuğla fabrikasından temin edilmiştir (http://www.sivaspostasi.com.tr/haber/ sivasin atelyeli yillari).

Sivas Cer Atölyesi, 22 Ekim 1939 tarihinde hizmete açılmış, başlangıçta daha ziyade vagon ve lokomotif onarımı yapılmıştır. Sivas'ın ilk büyük ve modern sanayi kuruluşu olan atölyenin hizmete girmesiyle şehir nüfusu artmış, fiziki olarak büyümüş; şehirde sosyal, ekonomik ve kültürel alanda önemli gelişmeler yaşanmıştır. Atölyenin ilk hizmete girdiği yıllarda iş gücüne ve teknik elemana ihtiyaç duyulmuştur.* Bu bağlamda kırsal kesimden, çevre illerden ve demiryolu sektörünün geliştiği Adapazarı ve Eskişehir gibi kentlerden göç almış ve şehrin nüfusu hızla artmışıtır. TÜIK verilerine göre 1935 yılında Sivas'ın 65118 olan şehir nüfusu, 1940 yılında 78 701'e, 1945 yılında ise 80 019'a yükselmiştir (Akbulut, 2007: 87). Öyle ki, 1938-1943 devresinde ilin toplam işçi sayıs1 5426'ya yükselmiştir. Atölyede 1943 yılında çalışan işçi sayısı ise 2600'dür. Bu verilere göre, Sivas'ta çalışan işçi sayının yarısına yakınının Cer Atölyesinde çalıştığı anlaşılmaktadır (Yıldırım, 1993: 251). Kentin fizikî olarak büyümesine bağlı olarak, yerleşim alanı demiryolu garının ve atölyenin bulunduğu İnönü Bulvarı boyunca gelişmeye başlamış, bir kısım tarım alanları imara açılmıș ve şehir mezarlığı ortadan kalkmıștır (Akbulut, 2009: 218; Foto 1).

"Günde 1200-1500 arası işçi çalı̧̧ıracak olan bu atölyedeki usta ve işçilerle memurların ikameti için 500 kadar lojman, okul, hastahane, işçi sarayı ve otel gibi yapıların yapımına da başlanılmıștır. Burada modern bir demiryolu mahallesi kurulacak ve burası Sivas'ta bayındırlık ve ilerlemenin örneğini oluşturacaktır" (Yıldırım, 1993: 250).

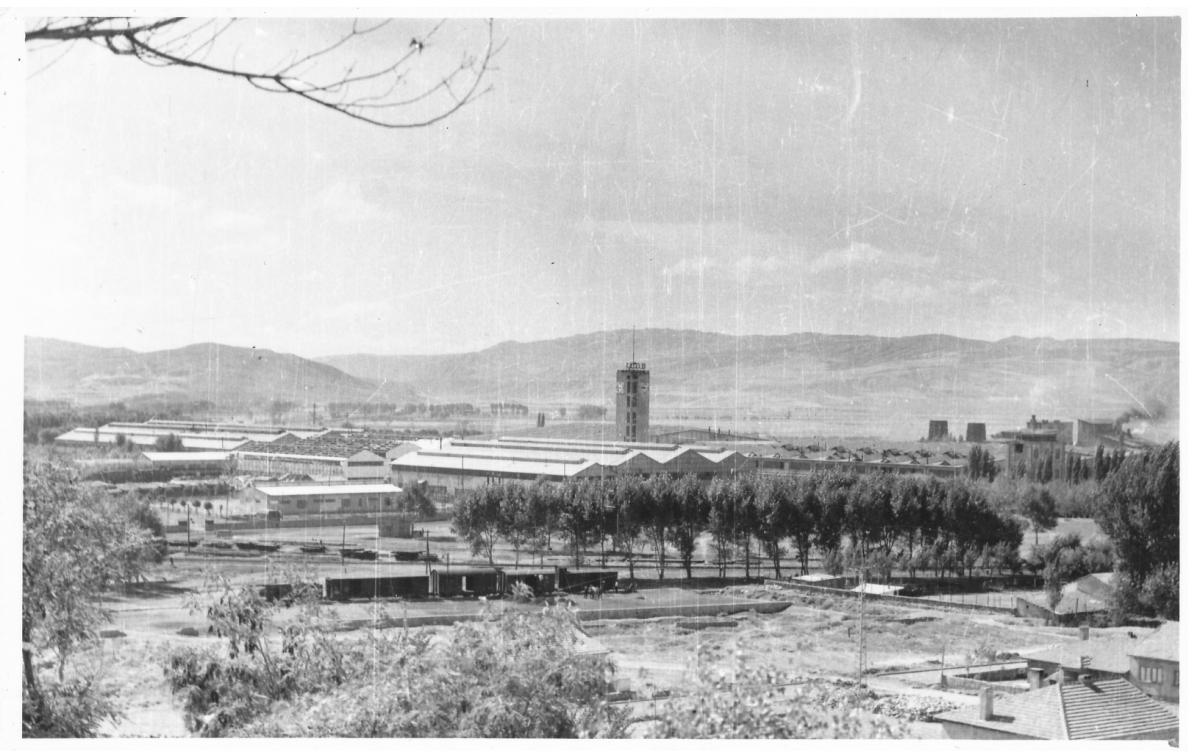

Foto 1: Sivas Cer Atölyesi etrafında bahçeli evler ve boş araziler görülmekte (Ahmet İzzet Göze arşivi).

\footnotetext{
* Ozan Özpay'ın Cer isimli belgeselinde bu dönemde atölyede çalışan işçiler, deneyimli işçilerin Eskişehir, Adapazarı ve İstanbul gibi büyük şehirlerden geldiklerini, atölyenin inşasında Alman mühendislerin çalıştı̆̆ını, sonraki yıllarda teknik eleman ihtiyacının çırak okulundan temin edildiğini ifade etmişlerdir (2019). Topgül'ün çalışmasında ise (2017); çırak okulunda öğrencilere dört yıllık bir eğitimin verildiği, öğrencilerin sigortalandığı, yevmiye aldığı ve giyecek ihtiyaçlarının karşılandığı, okul bitiminde işçi muavini ve sonrasında işçi olarak fabrikada çalıştıkları ve sosyal haklarının bulunduğu ifade edilmektedir.
} 
Zamanla atölye etrafında planlı bir şekilde lojmanlar yapılmış, yakın çevrede Yenişehir ve Altuntabak gibi yeni mahalleler ortaya çıkmıştır (Foto 2). Ayrıca Sivas Cer Atölyesi'nin termik santrali şehrin bir kısmının elektrik ve ısınma ihtiyacının karşılanmasına katkı sağlamıştır (Ökmen, 2001:256). Bu nedenle lojmanlar şehir halkının uğrak yerlerinden biri olmuştur. Sivas Cer Atölyesi'ne yakın mahallelerde sosyal yapı derinden etkilenmiştir. Örneğin şehrin seçkin mahallelerinden biri olan Kaleardı Mahallesi, İkinci Dünya Savaşını izleyen yıllarda Sivas Cer Atölyesi'nde çalışan işçilerin oturdukları mahalelelerden birine dönüşmüştür (Yıldırım, 1993: 252). Yine demiryolunun gelmesi ile şehirde otel sayısı artmış, Örnek, Cumhuriyet, Ankara Palas ve Emniyet adlarında yeni oteller inşa edilmiş, on iki adet han köylerden gelen işçilerin konaklamalarına ayrılmıştır (Üredi, 2006: 266).

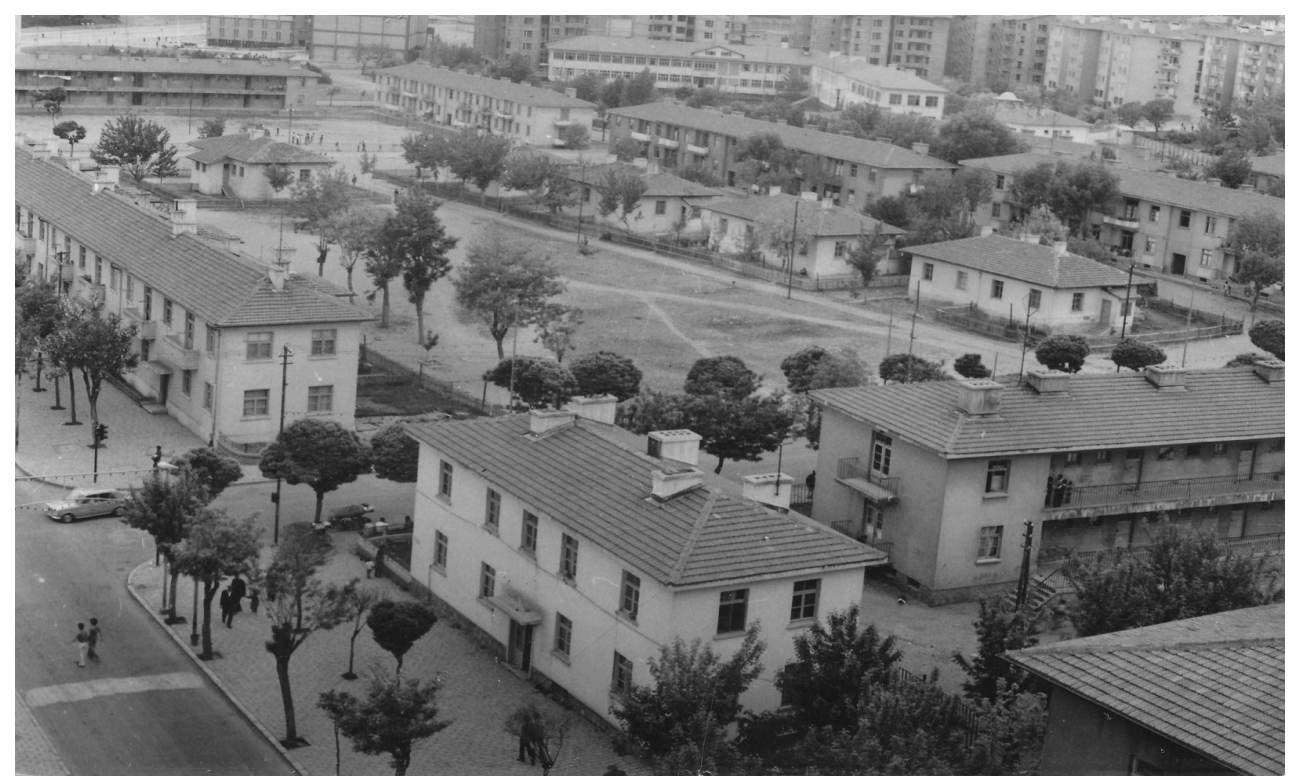

Foto 2: Sivas Cer Atölyesi’nin lojmanları (Ahmet İzzet Göze arşivi).

Sivas Cer Atölyesi zaman içerisinde bina, tezgâh ve tesisat bakımından gelişmiş ve 1953 yılında ilk kez yeni yük vagonları üretmeye başlamıştır. Atölye içinde lokomotif, vagon onarım ve üretim, döküm, lastik ve marangoz bölümleri açılmıştır. Ortadoğunun en büyük döküm fabrikası olan Sivas Cer Atölyesi, ülkede demiryollarının ihtiyaç duyduğu tüm işleri yaptığı gibi, Ereğli Demir Çelik fabrikasının kalıp ve pota dökümleri, gemi silindir gömlekleri, hatta çay ve dokuma fabrikalarının bir kısım parçalarını da üretmiştir (Önder, 1970: 59). 1960 yılında üretilen ilk yerli otomobil ‘Devrim' arabasının silindir bloku ve bazı önemli döküm parçaları burada imal edilmiştir. 1961 yılında ilk yerli buharlı lokomotif 'Bozkurt' da yine bu atölyede üretilmiştir (Koçarslan, 2016: 16). Atölye 1964 yılında maden vagonu üretimine başlamıştır. Lokomotiflerde kullanılan parçaların \% 90'1 ve demiryolları için gerekli olan her türlü lastik malzeme bu atölyeden temin edilmiştir (Önder, 1970: 59). Ülkenin o dönem en büyük demiryolu fabrikalarından biri olan atölyede 1960'ların sonlarında çalışan sayısı 6000 kişiye ulaşmış, ticari faaliyetler artmış ve şehir ekonomisi büyümüştür (Çubukçu, 1968: 25).

“...işçi lokali, sineması, spor tesisleri, trenlerde ücretsiz permisi, hastanesi, ailece ücretsiz muayene ve tedavisi, az bir ücret karşılığında atölyenin verdiği odun, kömür, Devlet Demiryollarının sahil şehirlerindeki özel kamplarında tatil yapma imkânları, büyüklerimizin ismini telaffuz etmekte zorlandıkları gıda satış kooperatifi ve yılda dört defa aldıkları ikramiye o senelerdeki bir atölye işçisinin çok iyi standarta sahiptir...

... Yine bu dönemde daha modern lokantalar, kahveler, gazinolar, pastaneler, firınlar hizmete açıldı. Atölye kuruluncaya kadar iki yüz kişişlik bir sinema ile yetinen Sivas’ta, Atölye kurulduktan sonra beş sinema birden perdelerini açarak Sivas halisinin durgun geçen yaşantısını hareketlendirdi. İşçi kesimin artması ticaret hayatına canlılık getirdi. Bu yüzden dükkânlar geceleri daha geç kapanmaya, her gece bir eczane nöbetçi kalmaya başladı. Şehrin caddelerinde o devrin son model taksileri görülebiliyordu" (Üredi, 2006: 265-267).

Sivas Cer Atölyesi’nin ismi zaman içerisinde birkaç kez değişmiştir. Atölye, 1958 yılında Sivas Demiryolu Fabrikaları, 1975 yılında Sivas Demiryolu Makinaları Sanayii Müessesesi (SIDDEMAS) ve 1986 yılında ise Türkiye Demiryolu Makinaları Sanayii Anonim Şirketi (TÜDEMSAŞ) adını almıştır. Atölyenin mazisi başarılarla doludur. Öyle ki; 1989 yılında Almanya’ya vagon parçası ihracatı yapılmıştır. 2007 yılında Türkiye'de 
ilk defa demiryolu araçlarının önemli bileşenlerinden biri olan bojili nitrik asit taşıma vagonu üretimi gerçekleştirmiştir (Afşin, 2014: 32-33; http://www.tudemsas.gov.tr/tudemsas/tr/HTML). Tesis günümüzde yaklaşık $110.000 \mathrm{~m}^{2}$ 'si kapalı olmak üzere, toplam $418.626 \mathrm{~m}^{2}$ lik bir alan üzerinde faaliyet göstermektedir (Koçarslan, 2016: 16).*

\subsection{Atölyenin Somut Kültürel Miras Ögeleri}

"Somut kültürel miras, tarihi binalar ve kentler, arkeolojik ve kültürel sitler, kültürel objeler ya da taşınabilir kültür varlıkları gibi maddi kültürel değerlerin tamamını içerir” (Yeşilbursa, 2013: 407). Bu kültürel miras taşınır ve taşınmaz olmak üzere ikiye ayrılır. Sivas Cer Atölyesi’nin alan sınırları içerisinde veya yakın çevresinde taşınır ve taşınmaz çok sayıda somut kültürel miras ögesi mevcuttur (Tablo 1).

Sivas şehrinin önemli simgeleri arasında yer alan ve yapıldığı dönemde şehrin her yerinden görülebilen ve sesi duyulan saat kulesi, atölyenin önemli taşınmaz kültürel miras ögelerinden biridir. 1939 yılında inşa edilen saat kulesi Sivas Cer Atölyesi'nin içinde yer almakta olup, mesai başlangıç ve bitiş saatleri ve günün belli zaman aralıklarında çalmaktadır. Halk arasında 'atölye borusu' olarak isimlendirilen saat kulesinin uzunluğu yaklaşık 44 metre olup, dikdörtgen şeklindeki kulenin dört tarafında saat vardır (https://www.haberturk.com/sivas-haberleri). Saat; kulesi, mimarisi ve boru sesi ile kültürel miras turizmi açısından önemli bir değer oluşturmakta ve ziyaretçilerin dikkatini çekmektedir. Demirci (2009), saatin ve boru sesinin şehir kültüründeki yerini şöyle ifade etmektedir;

“... Boru sesi yabancı idi ama alıştık; hayatımıza fabrikayı sokan ve mesai kavramına göre tanzim eden yeni çağın sesiydi; yeni bir çağa girişimizin jenerik müziğiydi. O ses eşliğinde Sivas ortaçağdan çıkarak, modern zamanlara adım atmıştır. Artık kalenin saati hükmünü yitirmiş, fabrikanın her saat başı çalan ve şehrin her yerinden duyulan kampanası, saatleri ayarlamanın yeni yolu olmuştur. Sadece fabrikada çalışanlar değil, vakitle ilgili her işte atölye borusu, şehrin muvakkidi gibiydi” (Demirci, 2009: 505).

Tablo 1: Sivas Cer Atölyesi Somut Kültürel Miras Öğeleri

\begin{tabular}{|l|l|}
\hline Taşınmaz Kültürel Miras & Taşınır Kültürel Miras \\
\hline Saat Kulesi & Fotograflar- Arşivler \\
\hline İdare Binası & Bozkurt Lokomotifi \\
\hline Sinema Binası & Sağlık Malzemeleri \\
\hline Model Binası & Plakalar \\
\hline Çırak Okulu & Flamalar \\
\hline Tahta Parke Zemin & Şahmerdan \\
\hline Demiryolu Müzesi & Devrim Motor Döküm Kalıb1 \\
\hline Gar Binası & Mutfak Malzemeleri \\
\hline Lojmanlar & Günlük Kiyafetler \\
\hline Oteller & Müzik Aletleri \\
\hline
\end{tabular}

Kaynak: Sivas Cer Atölyesinde tarafımızdan gerçekleştirilen gözlemlerden derlenmiştir.

Sivas Cer Atölyesi sahasında, 1939 yılında yapılan tarihi yapılar mevcuttur. Bunların en eskisi, atölyenin ilk açılışında inşa edilen tesis binası olup, günümüzde hizmet binası olarak kullanılmaktadır. Bunun yaklaşık 50 $\mathrm{m}$ batısında içerisinde sinema salonu, kafeterya ve rejisör odasının bulunduğu başka bir binayı görmek mümkündür. Sivas'ın en büyük sinemalarından biri, 1950 yılında burada halkın hizmetine açılmıştır. Avrupa ve Türk sinemasının seçkin filmlerin gösterildiği bu sinema salonu; sahnesi, perdesi, iç mimarisi ve sandalyeleri ile hâlen o dönemin izlerini taşımaktadır (Özpay, 2019). Ne yazık ki, sinema salonunun çatısı günümüzde bakımsızlıktan çökmüş ve malzemeler büyük ölçüde kullanılamaz hâle gelmiştir. Kültürel mirasın korunması açısından sinema salonunun aslına uygun bir şekilde yeniden restore edilmesi elzemdir (Foto3).

\footnotetext{
* 1939 yılında açılan Sivas Cer Atölyesi, $196.000 \mathrm{~m}^{2}$ lik bir saha üzerinde inşa edilmiştir. Binaların kapladığı alan ise 48000 $\mathrm{m}^{2} \operatorname{dir}$ (Yildirım, 1993: 249).
} 


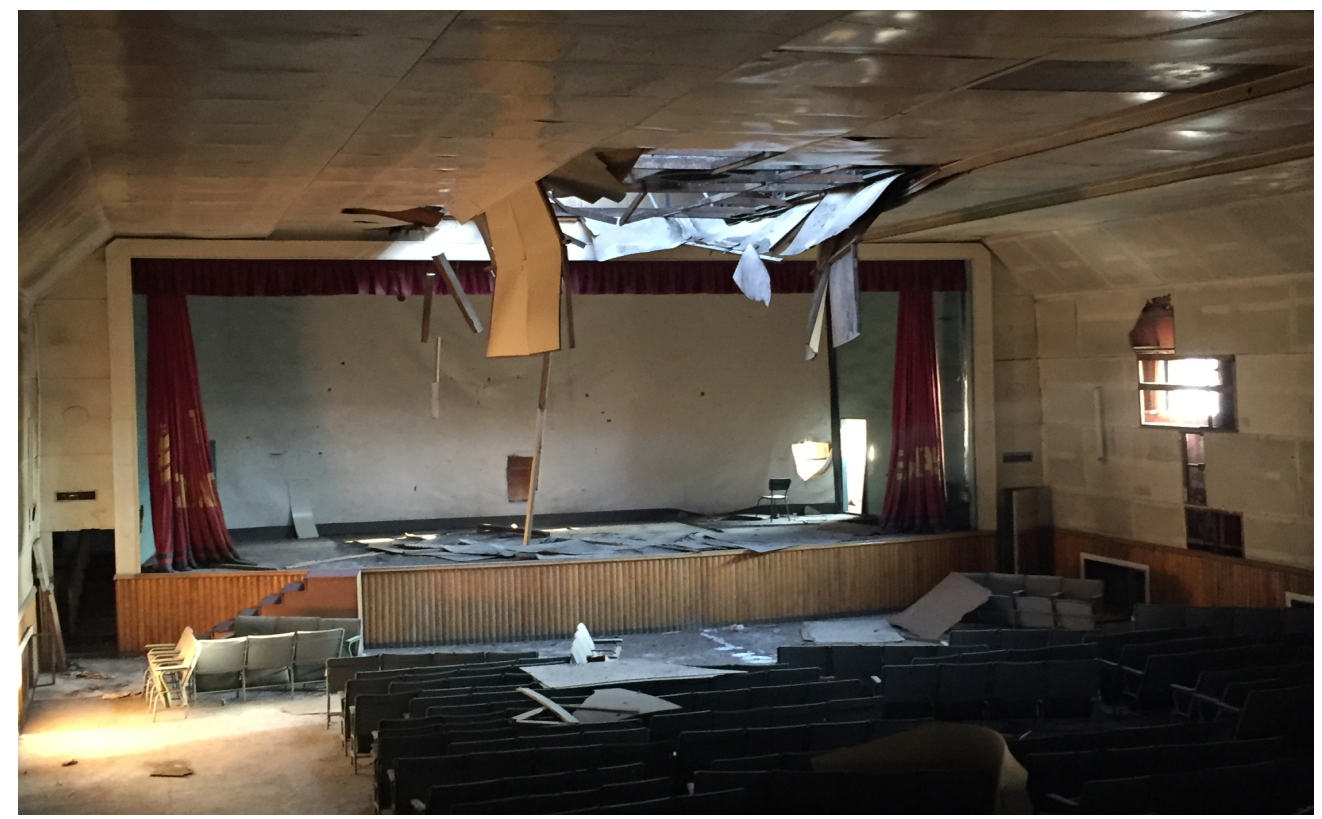

Foto 3: Cer atölyesinin sinema salonundan genel bir görünüm (Ozan Özpay arşivi).

Atölye alanındaki başlıca diğer tarihi taşınmazlar; model binası, çırak okulu, demiryolu müzesi, gar binası ve lojmanlardır. Bu binalar, 1940 öncesi Alman mimarisinin izlerini taşımaktadır*. İstasyon Caddesi üzerinde yer alan lojmanlar, şehre önemli bir kültürel kimlik kazandırmıştır. Bunlara ek olarak atölyenin 1930'larda inşa edilen giriş kapısı da dikkate değerdir (Foto 4).

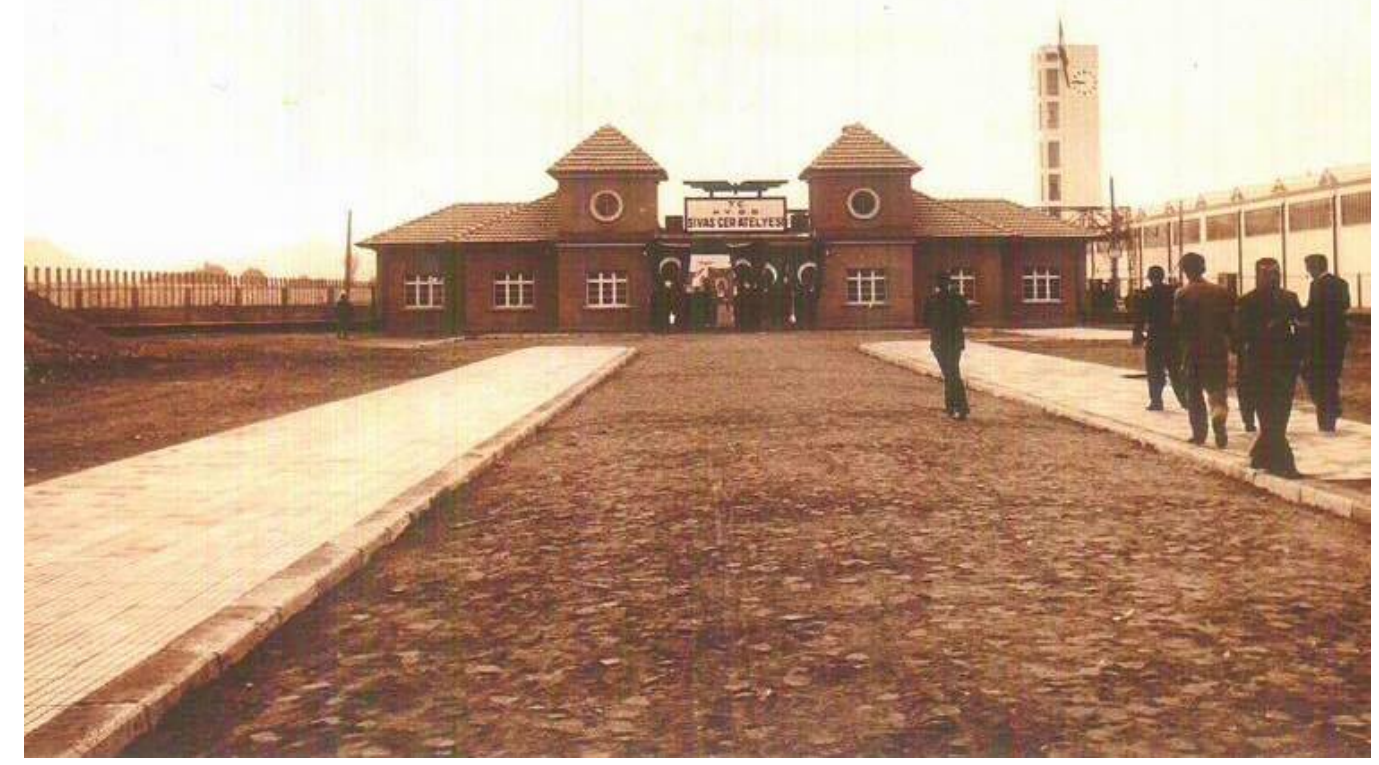

Foto 4: Sivas Cer Atölyesi’nin giriş kapısı (Ahmet İzzet Göze arşivi).

Taşınabilir kültürel miras ögelerinin önemli bir bölümü, günümüz itibariyle demiryolu müzesi içerisinde sergilenmektedir. Müze, 2011 yılında açılmıştır. Müzede sergilenen eserlerin başlıcaları; Osmanlı dönemine ait demiryolu plakaları, flamalar, fotoğraflar, demiryolu ve lokomotiflerle ilgili yağlıboya tabloları, örnek kimya labarotuvarı, tibbi malzemeler, gaz lambaları, çıraklık okulu bando takımının müzik aletleri, spor klüplerinin

\footnotetext{
* Cer Atölyesi, yerleşim itibariyle iki kısıma ayrılıyordu. Birinci kısım; lokomotif, vagon atölyeleri, takım, çırakhane, yıkanma ve yemekhane binaları, mağaza, açık hangarlar, su kulesi, doktor, kapıcı ve müdürlük binalarını ihtiva ederdi. İkinci kısım ise, memur ve işçi evlerinden müteşekkildi. Burada çalışacak mühendis ve işçinin sıhhi, kültürel ve sosyal ihtiyaçlarını karşılayan tesisatın önemli bir kısmı mevcuttu (Yıldırım, 1993: 250).
} 
kupaları, Devrim otomobili için yapılan motor bloklarının kalıbı, atölyede yapılan vagonların ilk örnek modelleri, demiryolu ve vagon parçaları, Türkiye'nin ilk yerli lokomotifi olan Bozkurt'un modeli ve dioraması, Bozkurt lokomotifinin yapılış aşamalarını gösteren fotoğraflar, işçi kartları ve basım makinası, günlük kıyafetler ve iş kıyafetleri, daktilolar, mutfak gereçleri, genel müdür odasının sergisi, sinema salonu ve makinesi, hesap makinesi, kişisel hediyeler, demiryolu armaları, kol düğmeleri ve demiryolu saatidir. Müze 2019 yılında geçici olarak hizmete kapanmıştır. Sergi binasında güçlendirme çalışmaları yapılması dolayısıyla, eserler depolarda korunmaktadır. Müzenin yıllık ziyaretçi sayısına yönelik herhangi bir istatistik bulunmamaktadır. Tespitlerimize göre müzeyi ağırlıklı olarak ortaöğretim ve üniversite öğrencileri ziyaret etmektedir.

Kültürel miras elemanlarından Bozkurt lokomotifi ve Şahmerdan, Sivas Cer Atölyesi’nin açık alanında sergilenmektedir. Bozkurt, Eskişehir'de üretilen Karakurt ile Türkiyenin ilk yerli lokomotifidir. Rutin bakımları yapılmakla birlikte; parça kayıpları, hareketsizlik ve meteorolojik olaylardan kaynaklanan eskime ve aşınma gibi sorunlar dolayısıyla lokomotif işlevini yitirmiştir (Foto 5-6). Lokomotifin kendini tanıtan bir de kitabesi bulunmaktadır. Kitabede;

"Ben Sivas demir yolu fabrikalarında Türk işçi ve mühendisinin el birliğiyle imal ettiği Bozkurt adlı 56202 nolu tamamen yerli ilk lokomotifim. 20 Kasım 1961'da TCDD'nin hizmetine girdim. Güzel yurdumu arkamda binlerce ton yükle doğudan, batıya, kuzeyden, güneye yüzlerce defa geçtim. Hizmet sırasında geçirdiğim sayısız rahatsızlık demir yolu personelince iyileştirildi. Yaklaşık 25 senelik hizmetin sonunda ekonomik ve teknik ömrümü doldurduğum gerekçesiyle emekli oldum. İmal edildiğim, ismi sonra değiștirilen ve gelișen TÜDEMSAȘ’ta 25 sene hizmet ettiğim raylarımın üstüne oturttular, boyadılar, bir gelin gibi süslediler. Etrafım çiçek ve çimenlerle donatıldı. Bulunduğum yerden kuşların cıvıltısı içerisinde, üretimi ve onarımı yapılan vagonların servise verilişini mutlulukla seyrediyorum. Rahatım, mutluyum, ilginize teşekkür ediyorum." yazılıdır.

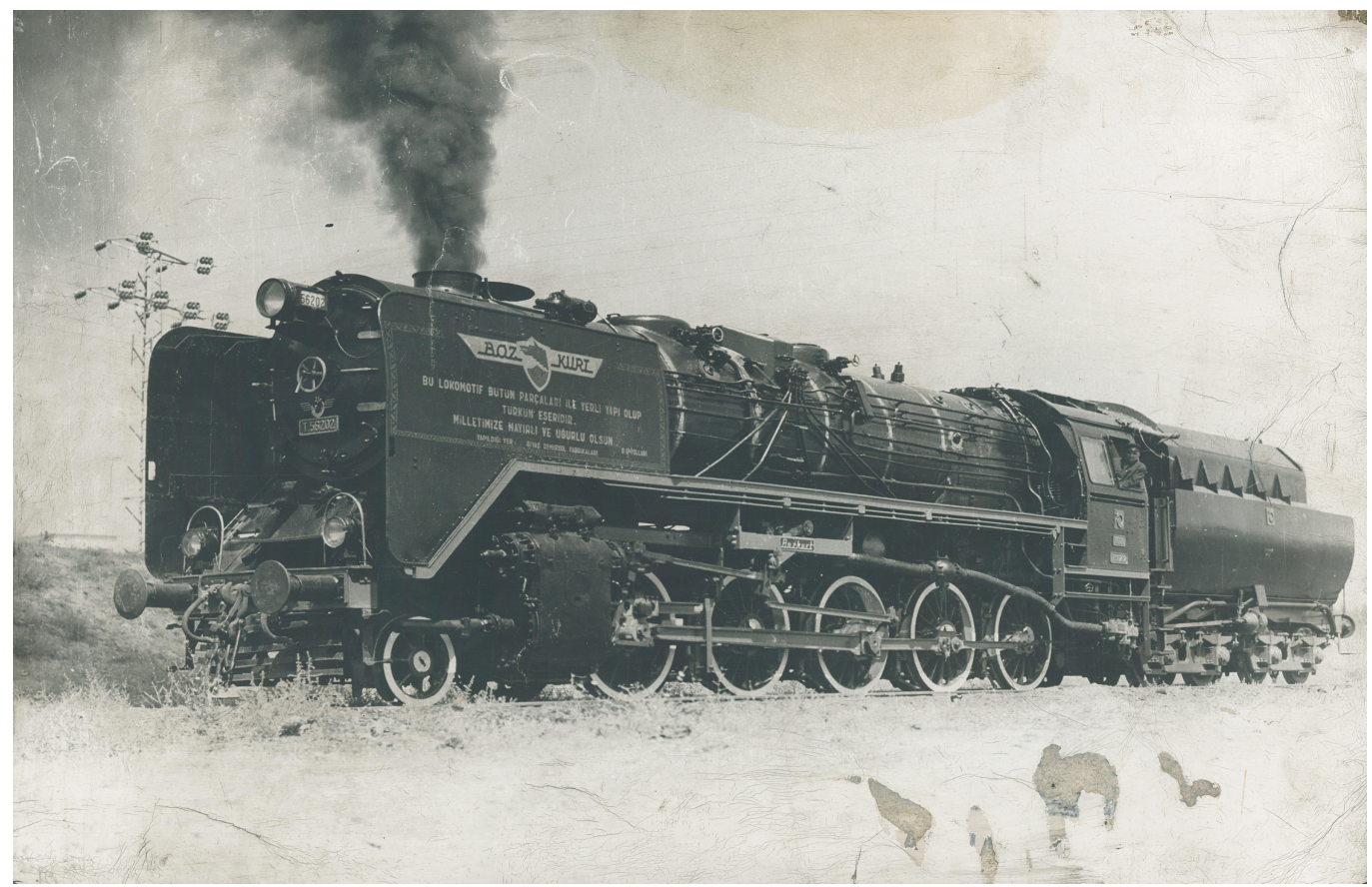

Foto 5: Sivas Cer Atölyesi'nde üretilen Bozkurt lokomotifi (Ahmet İzzet Göze arşivi).

Bunların dışında bir diğer varlık da, Sivas Gar Binası'dır. Eser, 1934 yılında hizmete açılmış olup, İnönü Bulvarı üzerinde yer alır. Dikdörtgen bir görünüme sahiptir. Yapı malzemesi olarak kesme taşın kullanıldı̆̆g, kuzey-güney yönünde iki ana giriş kapısının ve yüksek giriş holünün bulunduğu erken Cumhuriyet dönemi eserlerinden biridir. 


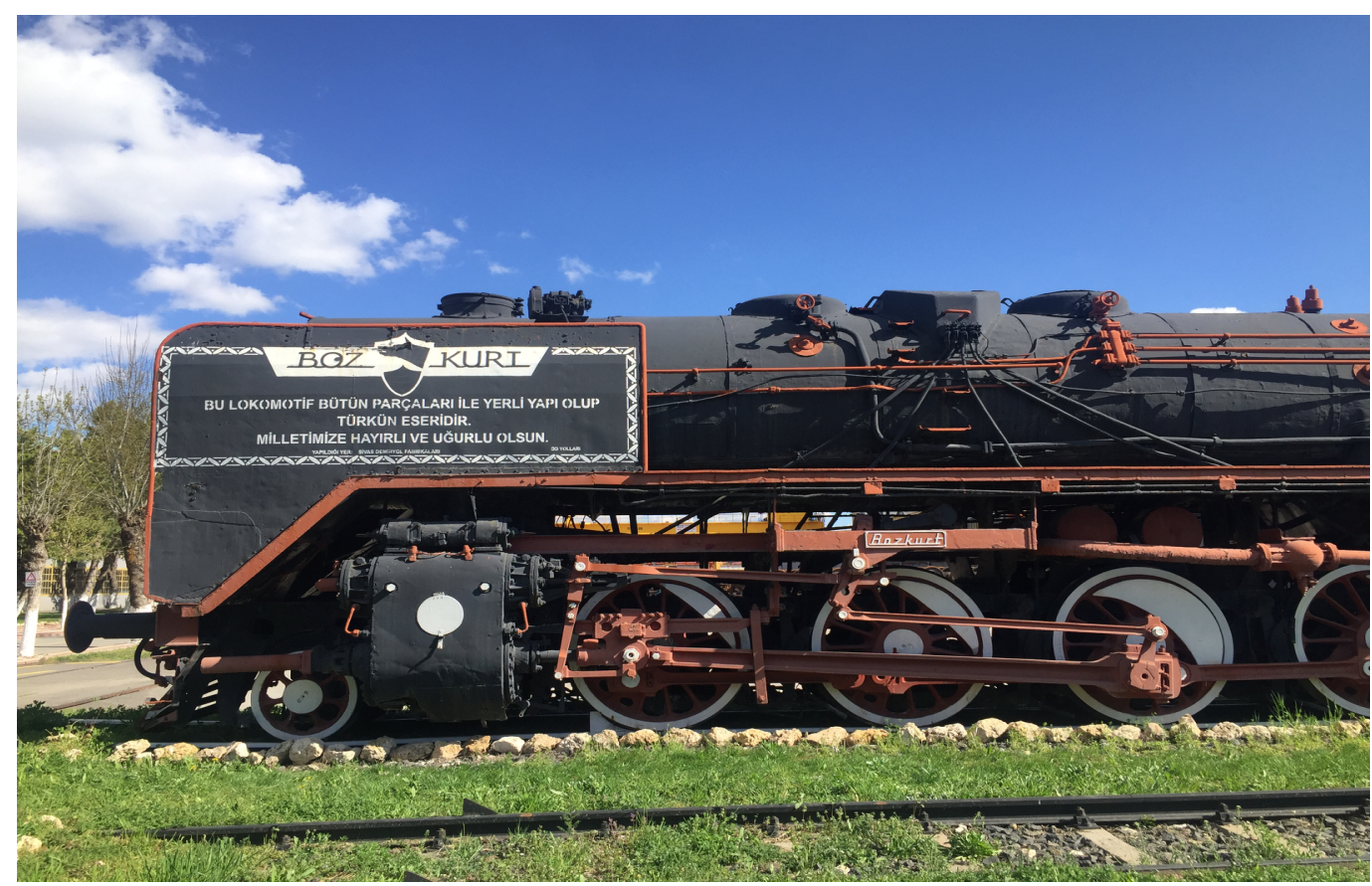

Foto 6: Günümüzde Sivas Cer Atölyesi’nde Bozkurt lokomotifi sergilenmektedir.

\subsection{Atölyenin Somut Olmayan Kültürel Miras Ögeleri}

"Somut olmayan kültürel miras; elle tutulamayan, gözle görülemeyen, buna karşın bir toplumu var eden değerlerdir. Bunlar; gelenek, dil, inanış, müzik, şarkı, dans, gösteri, tekerleme, hikâye ve şiir gibi unsurlardır." (Can, 2009: 1). Somut olmayan kültürel mirasın ne şekilde korunacağı, çırak-usta ilişkisinin nasıl olduğu, deneyim ve tecrübenin gelecek kuşaklara hangi yollarla aktarılacağ 1 , bu değerlerin hangi sosyal ve kültürel olayların etkisi ile oluştuğu önemli bir husustur (Metin Basat, 2013: 63). Sivas Cer Atölyesi’nde tarafımızdan gerçekleștirilen görüşmelerde atölye çalışanları geçmişte kurum içerisinde çeşitli tören ve şölenlerin yapıldığını, çıraklık okulu bando takımının milli bayramlarda şehirdeki törenlere katıldığını (Tablo 2; Foto 7), geleneksel spor oyunlarının oynandığını ve çeşitli müsabakaların yapıldığını ifade etmişlerdir.* Sivas’ta Cumhuriyet balolarının yapıldığı yerlerden biri de cer atölyesi olup (Foto 8), parlak geçmişinden dolayı Aşık Veysel Şatıroğlu'nun şiirine dahi konu olmuştur. Sivaslı büyük halk ozanı 'Ziyaret Eyledim Koca Sivas' $\imath$ ”' adlı şiirinde cer atölyesinden şu şekilde söz etmektedir (Kaya, 2011: 106);

\section{“Ziyaret eyledim koca Sivas' \\ Silindi gömlümün kalmadı pası \\ Durmayıp çalışır cer atelyesi \\ Gittikçe artıyor şanı Sivas'ın."}

Tablo 2: Sivas Cer Atölyesi Somut Olmayan Kültürel Miras Öğeleri

\begin{tabular}{|l|l|}
\hline \multicolumn{2}{|c|}{ Somut Olmayan Kültürel Miras } \\
\hline Tören ve Şölenler & Eğitim Videoları \\
\hline Demiryolu Hikâyeleri & Boru Sesi \\
\hline Geleneksel Oyunlar & Demirspor \\
\hline
\end{tabular}

Kaynak: İlgili literatürden ve tarafımızdan gerçekleştirilen mülakatlardan derlenmiştir.

Bunların dışında, saat kulesinden çıkan boru sesi de somut olmayan kültürel miras ögelerinden biri olarak değerlendirilebilir. Sivas halkı kompsesör desteği ile saat kulesine pompalanan havanın çıkardığı bu ses sayesinde

\footnotetext{
* Sivas Cer Atölyesi'nde somut olmayan kültürel mirasa yönelik bir kısım bilgiler, çalışanlarla yapılan mülakatlardan derlenmiştir. Kaynak kişilerin isimleri araştırmacılarda kayıtlı olup, metin içerisinde zikredilmemiştir.
} 
yakın zamana kadar vakitten haberdar olur, randevu saatlerini belirler ve gün içerisindeki işlerini düzenlerdi. Günümüzde gerek zamanı tayin ve tespite olanak sağlayan teknolojik alaetlerin yaygınlaşması, gerekse şehrin farklı yönlere doğru giderek büyümesinden dolayı saat kulesine duyulan ihtiyaç azalmıştır. Nitekim sesi kısılarak sadece fabrika ve yakın çevresinde işitilecek düzeye indirgenmiştir. Bununla birlikte Atatürk'ün ölüm yıl dönümlerinde, 10 Kasım saat 09.05 'te yüksek siren sesi şehre bu kuleden yayılmaktadır. Seksen yıldır bu ritüel düzenli olarak tekrarlanmakta olup, şehrin önemli geleneklerinden biri haline gelmiştir.

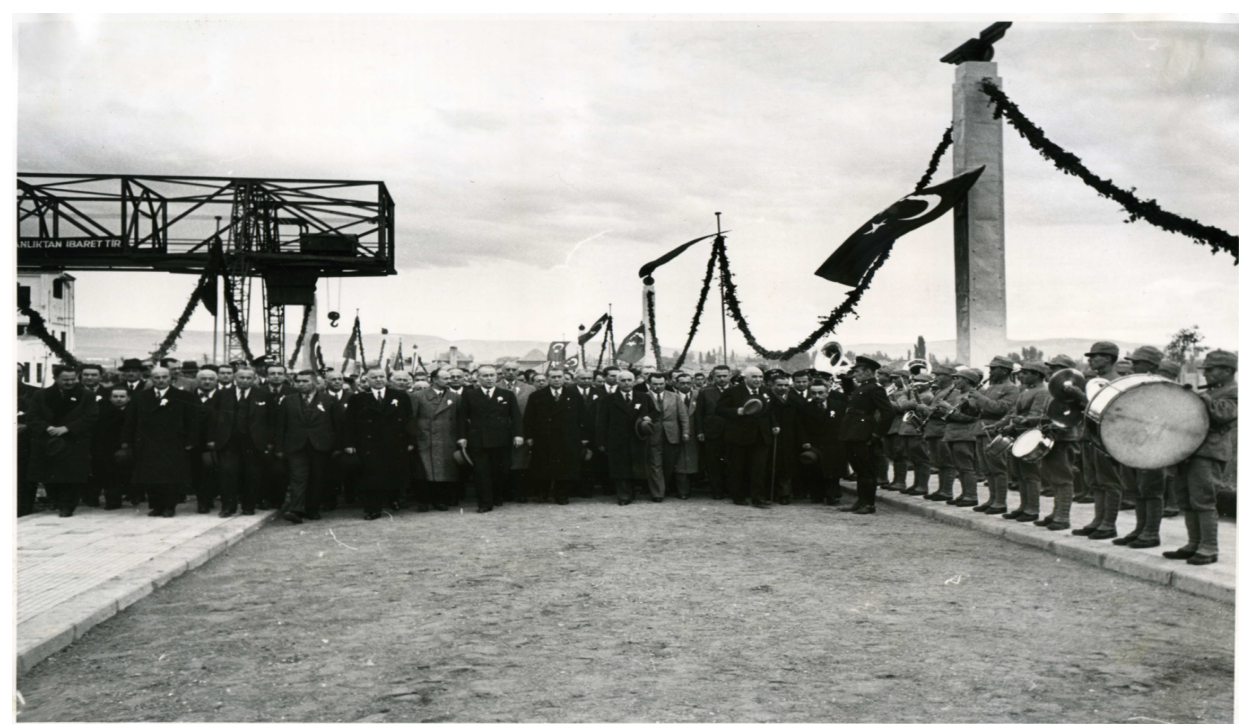

Foto 7: Sivas Cer Atölyesi bando takımı (Ahmet İzzet Göze arşivi).

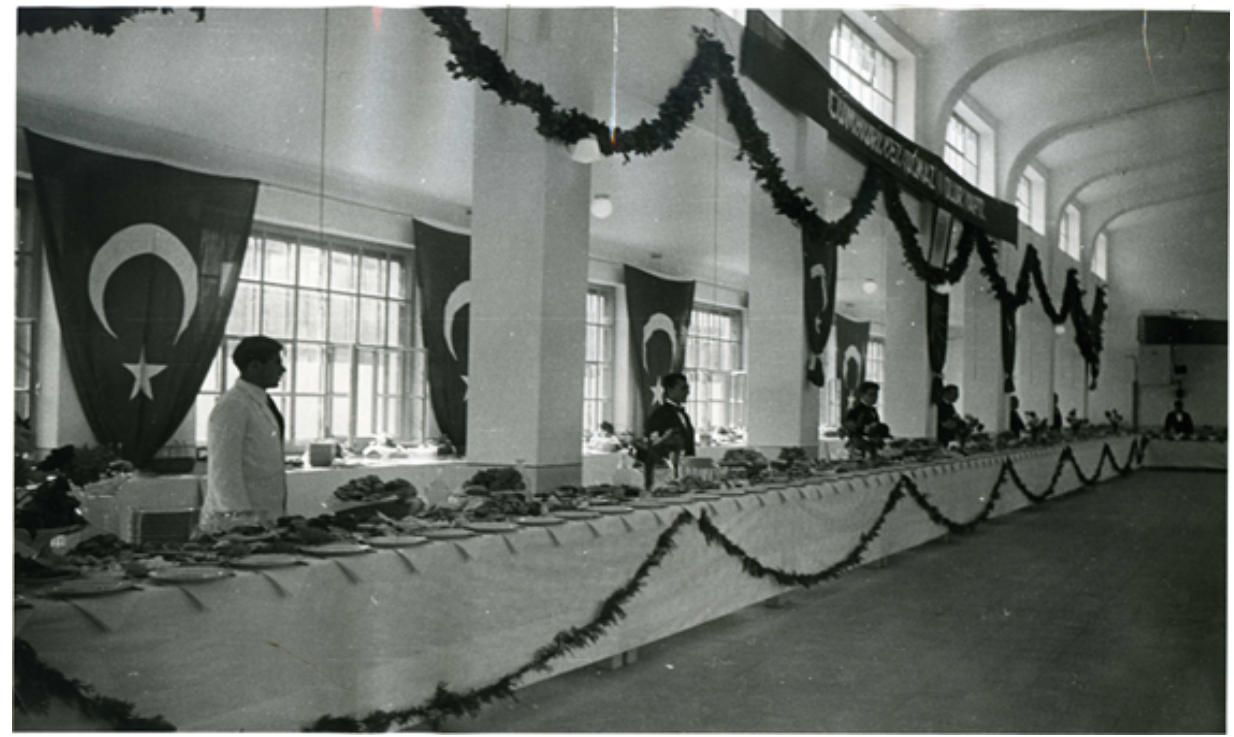
arşivi)

Foto 8: Geçmişte Sivas Cer Atölyesi’nde yapılan Cumhuriyet balolarından bir görünüm (Mehmet Erdinç

Çıraklık okulu, cer atölyesinin geleneksel yapısının oluşmasına katkı sağlayan önemli bir birimdir. Türkiye'nin ilk çıraklık okulları, 1942 yılında Sivas ve Eskişehir'deki cer atölyelerinde açılmıştır (Uçum, 2009: 4). Öğrenciler uzun yıllar boyunca bu okullarda ilgi alanlarına göre usta-çırak ilişkisi çerçevesinde uygulamalı olarak eğitilmişlerdir. Atölyenin işçisini, ustasını, hatta amirini yetiştiren bu okullarda öğrencilere yönelik çeşitli sosyal, kültürel ve sportif etkinlikler de düzenlenmekteydi. Okulun bünyesinde futbol, halter, güreş, gülle ve atletizm gibi çeşitli alanlarda faaliyet gösteren spor kulüpleri mevcuttu (Topgül, 2017; Foto 9). 


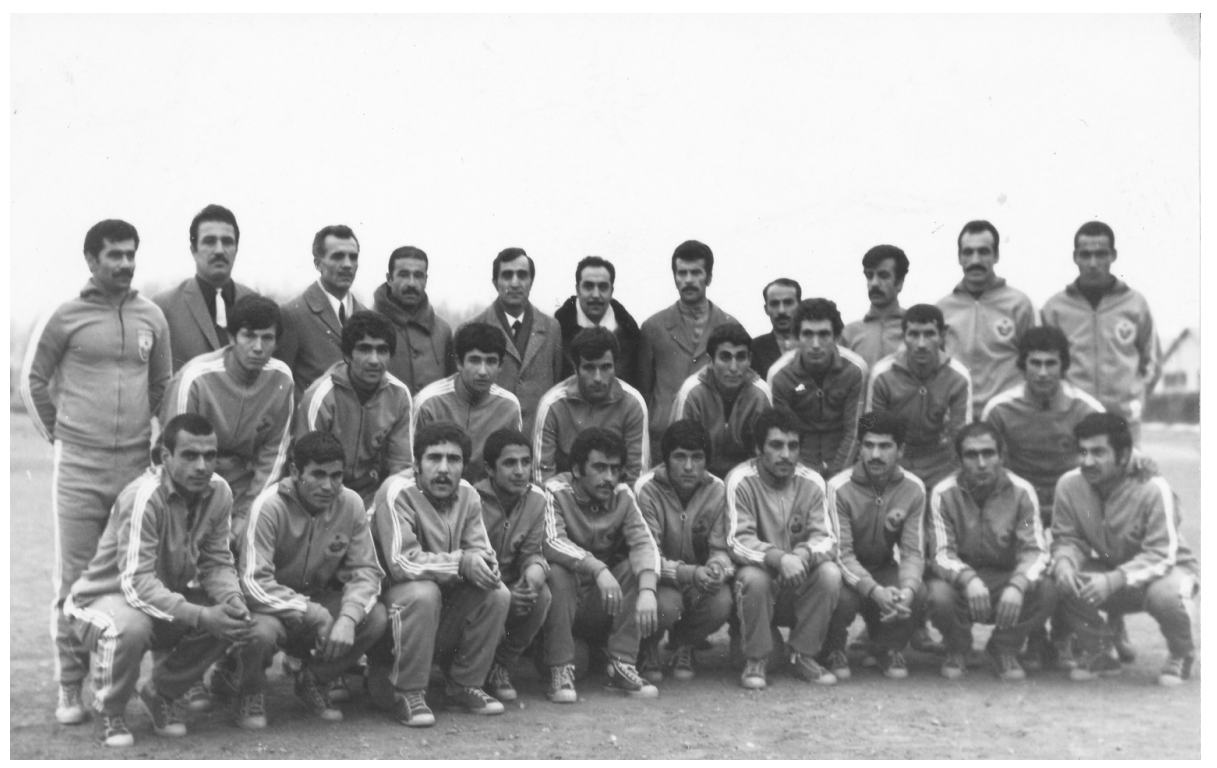

Foto 9: Cer atölyesi çırak okulunun futbol takımı olan Demirspor (Ahmet İzzet Göze arşivi ).

\section{Sonuç ve Öneriler}

Sivas Cer Atölyesi 22 Ekim 1939 tarihinde açılmış Türkiye Cumhuriyeti'nin ilk önemli sanayi tesislerinden biridir. $\mathrm{Bu}$ tesis içerisinde somut ve somut olmayan çok sayıda kültürel miras öğesi bulunmaktadır. Bunlar arasında tarihi yapılar, saat kulesi, demiryolu müzesi, vagon üretim tesisi, yemekhane, sinema salonu, lojmanlar, Bozkurt lokomotifi, tahta tuğlalı zeminler, fotoğraflar, resimler, arşiv belgeleri, formalar, saatler, törenler, kitabeler ve şiirler ön plana çıkmaktadır. Dolayısıyla hem Sivas'ın hem de Türkiye'nin dikkate değer kültürel miraslarından biridir. Bu mirasa dair yaklaşık 80 yıllık parlak geçmişin aydınlatılması ve kültürel ögelerin korunup, tanıtılması kültürel turizm açısından önem arz etmektedir. Bu çerçevede atölye alanında 2011 yılında açılan müze, içerisinde sergilenen yüzlerce materyal ile büyük bir boşluğu doldurmuştur. Ancak müze binasının 2019 yılında tadilata alınması nedeniyle sergi materyalleri depolara kaldırılmış ve ziyaretçilere geçici olarak kapatılmışır. Tadilatın en kısa sürede bitirilip, müzenin tekrar faaliyete geçmesi beklenmektedir. Ayrıca Türkiye'nin ilk yerli lokomotifi olan Bozkurt'un eksik parçaları tamamlanmak ve bakımı yapılmak suretiyle çalışır hale getirilip, ziyaretçilerin hizmetine sunulması kültürel mirasın sürdürülebilirliliği açısından önemlidir.

Sivas Cer Atölyesi'nin somut olmayan kültürel varlıklarının korunması ve gelecek kuşaklara aktarılmasında çeşitli zorluklar söz konusudur. Örneğin atölyenin ilk yıllarıyla ilgili bilgisine başvurulabilecek dönemin çalışan personelinin büyük bir kısmı bugün hayatta değildir. Dolayısıyla o dönem, ancak tarihi kayıtlardan ve belgelerden yararlanmak suretiyle aydınlatılabilir. Atölyenin şehrin sosyal, kültürel ve ekonomik hayatındaki yeri ve etkisine yönelik ilk belgesel, Ozan Özpay tarafından 2019 yılında çekilmiştir. Hayatta olan atölye çalışanlarının anlatımları çerçevesinde hazırlanan söz konusu belgesel, yakın tarihe ışık tutmaktadır. Bu kapsamda somut ve somut olmayan kültürel öğelerin envanterinin çıkarılması ve detaylı bir arşiv çalışmasının yapılması yararlı olacaktır.

Son olarak, yöre halkının toplumsal belleğinde önemli bir yer tutan Sivas Cer Atölyesi’nin tanıtılması, kültür turizmine kazandırılması ve gelecek kuşaklara daha iyi aktarılabilmesi için, tarafımızdan yapılan bu çalışma dışında başta tarih, sosyoloji ve ekonomi olmak üzere farklı disiplinlere mensup araştırmacıların yeni çalışmalarına ihtiyaç duyulduğunu belirtmek gerekir.

\section{KAYNAKLAR}

Afşin, C. (2014). Endüstriyel Atık Yönetimi ve Tüdemsaş Örneği. Cumhuriyet Üniversitesi Fen Bilimleri Enstitüsü Yayınlanmamış Yüksek Lisans Tezi, Sivas.

Akbulut, G. (2007). Sivas İli’nin Başlıca Nüfus Coğrafyası Özellikleri. Cumhuriyet Üniversitesi Sosyal Bilimler Dergisi. 31 (1), 83-100.

Akbulut, G. (2009). Sivas Şehrinin Tarihi Coğrafyası. Cumhuriyet Üniversitesi Sosyal Bilimler Dergisi, 33 (2), 212-222. 
Akpınar, E. (2007). Türkiye'nin Dünya Miras Listesi'ndeki yeri ve yeni bir aday önerisi. Erzincan Eğitim Fakültesi Dergisi, 9(1), 81-106.

Can, M. (2009). Kültürel Miras ve Müzecilik Çalışma Raporu (Eylül 2009), T.C. Kültür ve Turizm Bakanlığı, Ankara Erişim: Ekim, 23 2019, http://teftis.kulturturizm.gov.tr/Eklenti/1279,muserrefcanpdf.pdf?0

Çubukçu, N. (1968). Sivas İli Yakın Çevre Incelemesi. Ankara: Zühal Yayıncılık.

Demirci, B. (2009). İktisat Sosyolojisi Açısından Sivas Cer Atölyesi ve Değişen Zaman Bilinci. Cumhuriyet Döneminde Sivas Sempozyumu Bildirileri I (27-30 Ekim 2008), Sivas.

Girişken, M.U. (2010). Türkiye'de Kültürel Mirasın Korunmasında Yaşanan Sorunlar ve Jeodezik Yaklaşımlar, İstanbul Teknik Üniversitesi Fen Bilimleri Enstitüsü Yaınlanmamış Yüksek Lisans Tezi, İstanbul.

Kaya, D. (2011). Aşık Veysel. Ankara: Akçay Yayınları.

Koçarslan, Y. (2016). Mühendis Bakışı ile Milli Yük Vagonu Üretimi. Demiryolu Mühendisleri Derneği Dergisi, $3,15-18$.

Mahiroğulları, A. (2009). Cumhuriyet'ten Günümüze Sivas'ta Ekonomik Yapı ve İstihdam. Cumhuriyet Üniversitesi İktisadi ve İdari Bilimler Dergisi, 10 (1), 175-194.

Metin Basat, E. (2013). Somut ve Somut Olmayan Kültürel Mirası Birlikte Koruyabilmek. Milli Folklor, 25 (100), 61- 71.

Oğuz, M. Ö. (2013). Terim Olarak Somut Olmayan Kültürel Miras. Milli Folklor, 25 (100), 4- 13.

Ökmen, M. (2001). Sivas’ta kentsel gelişme, Cumhuriyet Üniversitesi, İ̈BF Dergisi, 2(1), 239-264.

Önder, K. (1970). Sivas İli Yakın Çevre İncelemeleri, Ankara: Nam Yayınları.

Özgüç, N. (1998). Turizm Coğrafyası (Özellikler-Bölgeler), İstanbul: Çantay Kitabevi.

Özpay, O. (2019). “CER” Belgeseli (22 Ekim 2019), Sivas.

Shaffer, C.S., Inglis, G.J. (2000). Influence of Social, Biophysical, and Managerial Conditions on Tourism Experiences Within the Great Barrier Reef World Heritage Area. Environmental Management, 26 (1): 7387.

Topgül, S. (2017). Tülomsaş Kuruluşu ve Kurulduğu Dönemdeki Çalışma İlişkilerinin Sözlü Tarihten Yararlanma Yolu İle İncelenmesi. Gümüşhane Üniversitesi Sosyal Bilimler Enstitüsü, 8 (21), 184-196.

Uçum, M. (2009). Çıraklık Eğitiminde Güncelliğini Yitiren ve Öğretim Kapsamına Alınacak Yeni Mesleklerin Belirlenmesi, Ankara: MEB Yayınları.

Üredi, K. (2006). Bir Şehrin Beş Hali, İstanbul: Ötüken Yayınları.

Yeşilbursa, C. C. (2013). Altıncı Sınıf Öğrencilerinin Somut Kültürel Mirasa Yönelik Görüşleri. Kastamonu Eğitim Dergisi, 21 (2): 405-420.

Yıldırım, H. (1993). Cumhuriyet Döneminde Sivas Şehri (1923-1950), Dokuz Eylül Üniversitesi Atatürk İlkeleri ve Inkılâp Tarihi Enstitüsü, Basılmamış Doktora Tezi, İzmir.

Yılmaz, Ö.Ö. (2005). Türkiye'de Kültürel Mirasın Sorunları ve Yönetimi, Gazi Üniversitesi Sosyal Bilimler Enstitüsü Yayınlanmamış Yüksek Lisans Tezi, Ankara.

https://www.haberturk.com/sivas-haberleri/68253244-zamani-bildiren-saat-kulesi-sesi- 80-yildir-susmadi. Erişim Tarihi: 11Nisan 2019.

http://www.sivaspostasi.com.tr/haber/sivasin_atelyeli_yillari. Erişim Tarihi: 11Nisan 2019.

http://www.tudemsas.gov.tr/tudemsas/tr/HTML Erişim Tarihi: 11Nisan 2019.

Ahmet İzzet Göze fotoğraf arşivi.

Mehmet Erdinç fotoğraf arşivi.

Ozan Özpay fotoğraf arşivi. 
Kültürel Mirasa Bir Örnek: Sivas Cer Atölyesi 